ISSN 0975-3311

UJBM, Vol. 8, No. 2, July - December 2009, pp 55-66

ISSN 0975-3311 | https://doi.org/10.12725/ujbm.15.6

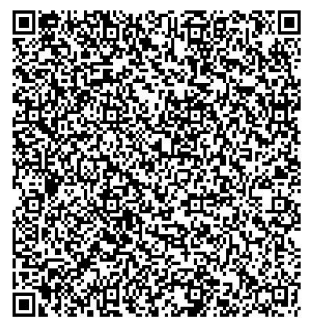

\title{
LEADERSHIP ORIENTATION IN INDIAN SMALL BUSINESSES
}

John Brinkman*, Tomy K. Kallaraka** \& Jain Mathew***

\section{ABSTRACT}

The paper considers how leadership is practiced currently in SMEs situated in the Bangalore region of India. Thus addressing the lack of research into leadership-in-practice noted by a number of authors (Stogdill, 1974; Bryman, 1992; Gronn \& Ribbins, 1996; Yukl, 2005) and hence the paper makes a contribution towards understanding of leadership within the Indian SME sector. The research focuses on the leader, not followers, and considers what leaders in SMEs do and would like to do.

The research project is descriptive and aims to give a snapshot of current views on leadership by Indian SME leaders. This was achieved by use of a 33-item questionnaire and semi-structured joint interviews. The questionnaire was constructed to consider leadership behaviours based on the three-dimensional taxonomy proposed by Yukl et al. (2002). Here three metacategories (Task-Oriented Behaviours,

* Dept. of Management and Computer Science, Liverpool Hope University, Hope Park, Liverpool. Email: brinkmi@hope.ac.uk

** Dept. of Tourism Studies, Christ University, Bangalore.E-mail: tomy.kk@christuniversity.in

***Dept. of Management Studies, Christ University. E-mail: jainmathew@christuniversity.in 
Relations-Oriented Behaviours \& Change-Oriented Behaviours) are categorised in line with the behaviours identified. This multidimensional model does not attempt to classify whether a leader is more focused on one area but to 'classify specific leadership behaviours' (Yukl, 2005).

\section{Introduction}

The difficulties with defining leadership are well documented (Dubrin 2000) and hence much research is, if not as noted by Bernard 'dogmatically stated nonsense', dismissed at a fundamental level by the confusing amount of definitions on what is a leader, manager, or indeed a mixture of both. Yet society increasingly is bemoaning the lack of leadership and looking for better leaders which would in turn lead to correspondingly improved performance. For Small to Medium Enterprises (SMEs), who generally do not have the resources, both money and staff time, for training and investment in leadership skills (Barrier, 1994; McAdam, 2000), the vast array of literature upon which leadership approaches to take compounds the issues. Much of the literature is based on large organisations but small organizations have different organizational structures, management styles and culture (Man et al., 2001). Also SMEs, due to their size and structure, generally have nobody within the business with whom to benchmark leadership in their context and most Indian SMEs are working in isolation. For example, most leaders in Indian SMEs lack awareness regarding the need for forming clusters to enhance their access to new technology and competitiveness (Stuti Kacker, 2005). This general isolation is a significant disadvantage. SMEs of developing countries have had to drastically adjust to the process of globalization moving from a state of temporary and involuntary dependence on the more powerful to one of voluntary interdependence. The development of clusters and agglomerations of enterprises in regional towns to meet regional/local consumer demands are considered significant and provide potential for small industry growth. Large organisations recognise leadership within their particular context, hence employees can identify with leadership within this structure and, importantly, they are continually exposed to leadership traits, good and bad, which are appropriate to their situation.

The paper considers how leadership is practiced currently in a number $(n=56)$ of SMEs situated in the Bangalore region of India. Thus addressing the lack of research into leadership-in-practice noted by a number of authors (Stogdill, 1974; Bryman, 1992; Gronn \& Ribbins, 1996; Yukl, 2005 ) and hence the paper makes a contribution towards understanding 
of leadership within the Indian SME sector. The research focuses on the leader, not followers, and considers what leaders in SMEs do and would like to do.

A range of criteria can be used to identify SMEs however, along with a number of authors (Atkins \& Lowe, 1996), employee numbers will be used. Hence for the purposes of this article an SME is defined as an enterprise with less than 250 employees.

\section{Research context and Objectives}

The paper will consider how leadership is practiced currently in SMEs situated in the Bangalore region of India and focuses on the leader, not followers, by considering what leaders in Indian SMEs currently do, or would like to do given the opportunity.

Hence the specific aims of this research are to; understand how the leaders practice leadership in their particular context, to establish the extent of the use of the three different taxonomies within the sector and to identify specific areas in which it may be beneficial for Indian SMEs to seek further training.

The leaders interviewed, 53 male and 3 female, $67.8 \%$ of whom had been in post for more than five years, identified their businesses as follows.

\begin{tabular}{|l|c|c|c|}
\hline Type of Organisation & Frequency & Percent & Valid Percent \\
\hline Public Limited Company & 1 & 1.8 & 1.8 \\
Private Company & 17 & 30.4 & 30.4 \\
Partnership & 8 & 14.3 & 14.3 \\
Private Ltd-SME & 24 & 42.9 & 42.9 \\
Manufacturing & 6 & 10.7 & 10.7 \\
Total & 56 & 100.0 & 100.0 \\
\hline
\end{tabular}

The age range of the leaders, along with the number of employees they have overall responsibility for are given below.

\begin{tabular}{|l|c|c|c|c|c|}
\hline $\begin{array}{l}\text { Age of } \\
\text { Leader }\end{array}$ & $20-30$ & $31-40$ & $41-50$ & $51-60$ & 61 and over \\
\hline Number & 12 & 12 & 24 & 7 & 1 \\
\hline
\end{tabular}




\begin{tabular}{|l|c|c|c|c|c|c|c|}
\hline $\begin{array}{l}\text { Employees } \\
\text { Line } \\
\text { Managed }\end{array}$ & $2-10$ & $11-20$ & $21-30$ & $31-40$ & $41-60$ & $61-99$ & $\begin{array}{c}100 \\
\text { and } \\
\text { over }\end{array}$ \\
\hline Number & 16 & 18 & 9 & 5 & 2 & 3 & 3 \\
\hline
\end{tabular}

Additionally only $34 \%$ of the leaders reported that they had received any training or mentoring over in the last three years.

\section{Research approach}

The research project is descriptive and aims to give a snapshot of current views on leadership held by Indian SME leaders. This was achieved by use of a 33-item questionnaire and semi-structured joint interviews. The questionnaire was constructed to consider leadership behaviours based on the three-dimensional taxonomy proposed by Yukl ef al. (2002). The questions used in this study are taken from the procedures listed in Yukl (2005) and were focused on two types of response to each of the behaviours listed. The first nine questions relate to task-oriented behaviours, the next 11 questions to relations-oriented behaviour and the final 13 questions to change-oriented behaviours. The first response to each behaviour asked the interviewees to consider if they 'currently do' Often, Rarely or Never. The second, in response to the same behaviour, was to consider if they 'would like to do' Often, Occasionally or Not at All. The responses were designed to measure magnitude of their commitment to each procedure, as opposed to frequency to a particular procedure. The questionnaires also recorded some personal and company information and they were completed in Bangalore during the months of November and December, 2006.

\section{Findings}

Although the participants were from different industry sectors the questionnaires produced many similarities giving some justification to the claim that the behaviours are 'potentially applicable to all types of leaders in organisations' (Yukl et al., 2002: 17). The average occurrences in each of the behavioural categories by the respondents are summarised below. 
Average Overall Responses in Percentages

\begin{tabular}{|l|c|c|c|c|c|c|}
\hline Behaviour & \multicolumn{3}{|c|}{ Currently Do } & \multicolumn{3}{c|}{ Would Like to Do } \\
\hline & Offen & Rarely & Never & Often & Occasionally & Not at All \\
\hline Task-oriented & 69.43 & 24.80 & 5.77 & 73.21 & 24.61 & 2.20 \\
Relations-oriented & 54.30 & 37.06 & 8.65 & 62.25 & 31.56 & 6.18 \\
Change-oriented & 45.22 & 45.95 & 8.85 & 62.28 & 31.67 & 6.05 \\
\hline
\end{tabular}

These indicate that there is a closer relationship with respect to task-oriented behaviour than either relations-oriented or change-oriented behaviour. The biggest discrepancy between would like to do, compared to currently do, is in the change-oriented category. This is also the only category with a bigger average 'rarely' response than 'often'. This seems to indicate that the SME leaders recognise the need to more change-oriented behaviours but are currently finding this difficult to achieve.

The responses from the leaders to the individual categories are shown with respect to the particular related activity below.

\section{Task-Oriented Behaviours}

The responses from the questionnaire with respect to task-oriented behaviours are listed below.

\begin{tabular}{|l|c|c|c|c|c|c|}
\hline Procedure(n=56) & \multicolumn{3}{|c|}{ Currently Do? } & \multicolumn{3}{c|}{ Would Like to Do? } \\
\hline & Often & Rarely & Never & Often & Occasionally & Not at All \\
\hline $\begin{array}{l}\text { Organise work } \\
\text { activities to improve } \\
\text { efficiency } \\
\begin{array}{l}\text { Plan short-term } \\
\text { operations }\end{array}\end{array}$ & $69.6 \%$ & $25 \%$ & $5.4 \%$ & $71.4 \%$ & $28.6 \%$ & $0 \%$ \\
$\begin{array}{l}\text { Assign work to } \\
\text { groups or individuals } \\
\text { Clarify what results are } \\
\text { expected for a task }\end{array}$ & $80.4 \%$ & $16.1 \%$ & $3.6 \%$ & $71.4 \%$ & $26.8 \%$ & $1.8 \%$ \\
\hline
\end{tabular}




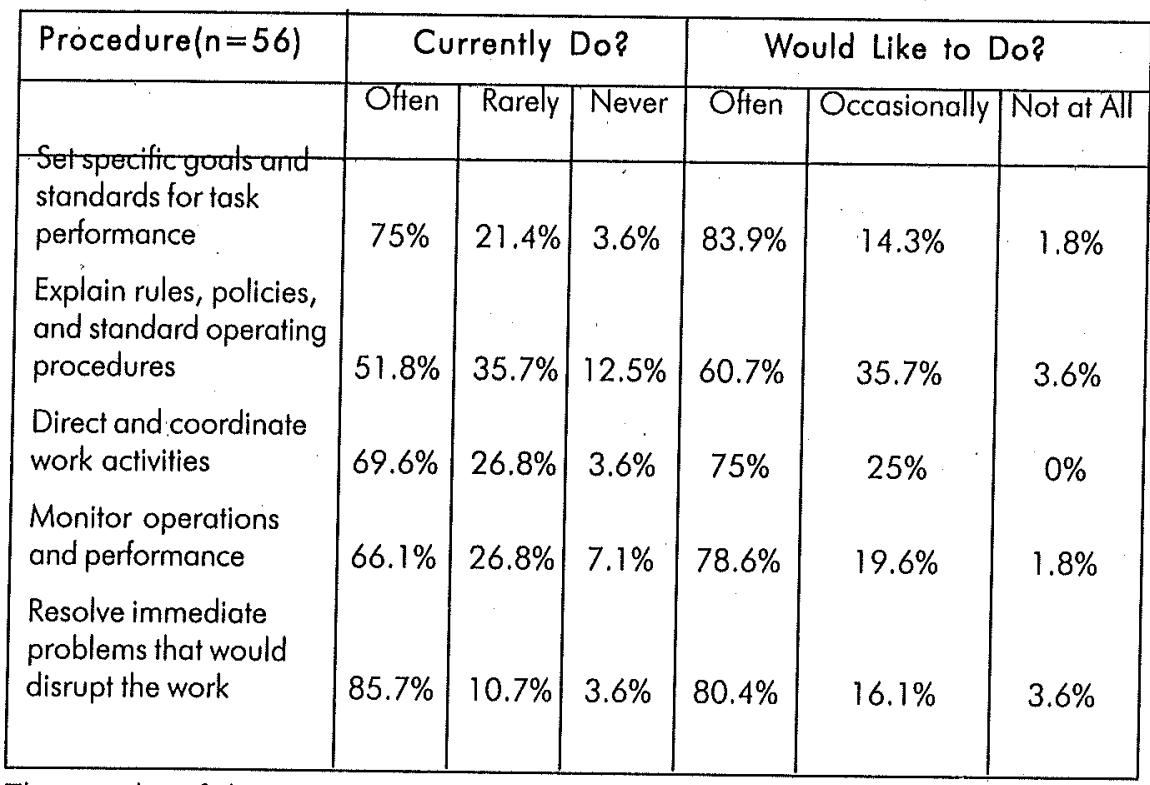

The results of the survey indicate that there is a good match between what leaders currently do and would like to do in relation to task-oriented behaviour. There are a number of categories however with a difference of more than $5 \%$ indicating that on average the SME leaders would like to spend more time on the following activities, displayed in order of preference:

- Set specific goals and standards for task performance

- Clarify what results are expected for a task

- Monitor operations and performance

- Direct and coordinate work activities

- Explain rules, policies, and standard operating procedures

They would like to spend less time doing the following:

- Resolve immediate problems that would disrupt the work

- Assign work to groups or individuals

The biggest gap between 'currently do' and 'would like to do' is $12.5 \%$ for Monitor operations and performance. Also there were two activities that none of the leaders would like to 'not do at all'. These are Organise work activities to improve efficiency and Direct and coordinate work activities. 


\section{Relations-Oriented Behaviours}

The responses from the questionnaire with respect to relations-oriented behaviours are listed below.

\begin{tabular}{|l|c|c|c|c|c|c|}
\hline Procedure(n=56) & \multicolumn{3}{|c|}{ Currently Do? } & \multicolumn{3}{c|}{ Would Like to Do? } \\
\hline & Often & Rarely & Never & Often & Occasionally & Not at All \\
\hline $\begin{array}{l}\text { Provide support and } \\
\text { encouragement to } \\
\text { someone with a } \\
\text { difficult task }\end{array}$ & $75 \%$ & $25 \%$ & $0 \%$ & $73.2 \%$ & $26.8 \%$ & $0 \%$ \\
$\begin{array}{l}\text { Express confidence } \\
\text { that a person or group } \\
\text { can perform a } \\
\text { difficult task }\end{array}$ & $60.7 \%$ & $32.1 \%$ & $7.1 \%$ & $75 \%$ & $25 \%$ & $0 \%$ \\
$\begin{array}{l}\text { Socialize with people } \\
\text { to build relationships }\end{array}$ & $55.4 \%$ & $35.7 \%$ & $8.9 \%$ & $67.9 \%$ & $23.2 \%$ & $8.9 \%$ \\
$\begin{array}{l}\text { Recognize contributions } \\
\text { and accomplishments }\end{array}$ & $66.1 \%$ & $30.4 \%$ & $3.6 \%$ & $69.6 \%$ & $28.6 \%$ & $1.8 \%$ \\
$\begin{array}{l}\text { Provide coaching } \\
\text { and mentoring when } \\
\text { appropriate }\end{array}$ & $42.9 \%$ & $51.8 \%$ & $5.4 \%$ & $60.7 \%$ & $37.5 \%$ & $1.8 \%$ \\
$\begin{array}{l}\text { Consult with people } \\
\text { on decisions affecting } \\
\text { them } \\
\text { Allow people to } \\
\text { determine the best } \\
\text { way to do a task } \\
\text { Keep people } \\
\text { informed about } \\
\text { actions affecting them } \\
\text { Help resolve conflicts } \\
\text { in a constructive way } \\
\text { Use symbols, } \\
\text { ceremonies, rituals } \\
\text { and stories to build } \\
\text { team identity } \\
\text { Recruit competent } \\
\text { new members for the } \\
\text { team or organization }\end{array}$ & $67.3 \%$ & $45.5 \%$ & $7.3 \%$ & $62.5 \%$ & $33.9 \%$ & $3.6 \%$ \\
\hline
\end{tabular}


There is slightly more variation here between what leaders currently does and would like to do. Again using the categories with a difference of more than $5 \%$ for 'currently do' and 'would like to do', indicates that the leaders would like to spend more time doing the following, displayed in order of preference, than they are currently;

- Help resolve conflicts in a constructive way

- Express confidence that a person or group can perform a difficult task

- Socialize with people to build relationships

- Keep people informed about actions affecting them

- Provide coaching and mentoring when appropriate

- Recruit competent new members for the team or organization

- Use symbols, ceremonies, rituals and stories to build team identity

There are no activities here that have a difference of more than $5 \%$, the leaders would like to spend less time doing than they currently do. The biggest gap between 'currently do' and 'would like to do' is $17.8 \%$ for Provide coaching and mentoring when appropriate. There are two activities that no leader thought they should not do at all. These are Provide support and encouragement to someone with a difficult task and Express confidence that a person or group can perform a difficult task.

\section{Change-Oriented Behaviours}

The responses from the questionnaire with respect to change-oriented behaviours are listed below.

\begin{tabular}{|l|c|c|c|c|c|c|}
\hline Procedure $(\mathrm{n}=56)$ & \multicolumn{3}{|c|}{ Currently Do? } & \multicolumn{3}{c|}{ Would Like to Do? } \\
\hline & Often & Rarely & Never & Often & Occasionally & Not at All \\
\hline $\begin{array}{l}\text { Monitor the external } \\
\text { environment to detect } \\
\text { threats and } \\
\text { opportunities }\end{array}$ & $51.8 \%$ & $37.5 \%$ & $10.7 \%$ & $60.7 \%$ & $33.9 \%$ & $5.4 \%$ \\
$\begin{array}{l}\text { Interpret events to } \\
\text { explain the urgent } \\
\text { need for change }\end{array}$ & $50 \%$ & $44.6 \%$ & $5.4 \%$ & $67.9 \%$ & $26.8 \%$ & $5.4 \%$ \\
\hline
\end{tabular}




\begin{tabular}{|c|c|c|c|c|c|c|}
\hline \multirow[t]{2}{*}{ Procedure $(n=56)$} & \multicolumn{3}{|c|}{ Currently Do? } & \multicolumn{3}{|c|}{ Would Like to Do? } \\
\hline & Often & Rarely & Never & Often & Occasionally & Not at All \\
\hline $\begin{array}{l}\text { Study competitors and } \\
\text { outsiders to get ideas } \\
\text { for improvements }\end{array}$ & $73.2 \%$ & $21.4 \%$ & $5.4 \%$ & $83.9 \%$ & $14.3 \%$ & $1.8 \%$ \\
\hline $\begin{array}{l}\text { Envision exciting new } \\
\text { possibilities for the } \\
\text { organization }\end{array}$ & $57.1 \%$ & $37.5 \%$ & $5.4 \%$ & $73.2 \%$ & 2) $4 \%$ & $5.4 \%$ \\
\hline $\begin{array}{l}\text { Encourage people to } \\
\text { view problems or } \\
\text { opportunities in a } \\
\text { different way }\end{array}$ & $38.2 \%$ & $56.4 \%$ & $5.5 \%$ & $76.4 \%$ & $23.6 \%$ & $0 \%$ \\
\hline $\begin{array}{l}\text { Develop innovative } \\
\text { new strategies linked } \\
\text { to core competencies }\end{array}$ & $48.2 \%$ & $48.2 \%$ & $3.6 \%$ & $69.6 \%$ & $30.4 \%$ & $0 \%$ \\
\hline $\begin{array}{l}\text { Encourage and } \\
\text { facilitate innovation } \\
\text { and entrepreneurship } \\
\text { in the organization }\end{array}$ & $49.1 \%$ & $47.3 \%$ & $3.6 \%$ & $70.9 \%$ & $27.3 \%$ & $1.8 \%$ \\
\hline $\begin{array}{l}\text { Encourage and } \\
\text { facilitate collective } \\
\text { learning in the team or } \\
\text { organization }\end{array}$ & $51.8 \%$ & $39.3 \%$ & $8.9 \%$ & $60.7 \%$ & $30.4 \%$ & $8.9 \%$ \\
\hline $\begin{array}{l}\text { Experiment with new } \\
\text { approaches for } \\
\text { achieving objectives }\end{array}$ & $30.4 \%$ & $57.1 \%$ & $12.5 \%$ & $58.9 \%$ & $37.5 \%$ & $3.6 \%$ \\
\hline $\begin{array}{l}\text { Make symbolic changes } \\
\text { that are consistent with } \\
\text { a new vision or strategy }\end{array}$ & $39.3 \%$ & $46.4 \%$ & $14.3 \%$ & $48.2 \%$ & $42.9 \%$ & $8.9 \%$ \\
\hline $\begin{array}{l}\text { Encourage and } \\
\text { facilitate efforts to } \\
\text { implement major } \\
\text { change }\end{array}$ & $35.7 \%$ & $58.9 \%$ & $5.4 \%$ & $48.2 \%$ & $46.4 \%$ & $5.4 \%$ \\
\hline $\begin{array}{l}\text { Announce and } \\
\text { celebrate progress in } \\
\text { implementing change }\end{array}$ & $37.5 \%$ & $53.6 \%$ & $8.9 \%$ & $51.8 \%$ & $41.1 \%$ & $7.1 \%$ \\
\hline $\begin{array}{l}\text { Influence outsiders to } \\
\text { support change and } \\
\text { negotiate agreements } \\
\text { with them }\end{array}$ & $25.5 \%$ & $49.1 \%$ & $25.5 \%$ & $39.3 \%$ & $35.7 \%$ & $25 \%$ \\
\hline
\end{tabular}


There are significant differences here in relation to the change activities with none of the activities having less than a $5 \%$ difference for 'currently do' and 'would like to do'. In fact, they would like to spend more time doing all the activities than they currently do, the smallest difference being $8.9 \%$. There are also 4 activities with differences of more than $20 \%$, one having a difference of $38.2 \%$. These, in order of magnitude, are:

- Encourage people to view problems or opportunities in a different way

- Experiment with new approaches for achieving objectives

- Encourage and facilitate innovation and entrepreneurship in the organization

- Develop innovative new strategies linked to core competencies

The first and last of these activities listed above were also the only ones that none of the leaders thought they should not be doing.

\section{Conclusions}

This specific aims of this piece of research were an attempt to; understand how the SME leaders practice leadership in their context, to establish the extent of the use of the three different taxonomies, and to identify specific areas in which it may be beneficial for Indian SMEs to seek further training.

That the behaviours in the questionnaire were applicable to leaders in all organisations, as claimed by Yukl et al. (2002), is borne out in this instance. We consider briefly the remaining two aspects below.

How the SME leaders practice leadership in their context is shown in detail in the findings. However it is generally the case that on average the leaders are spending more time on task behaviours $(69.43 \%$ ) than relations-oriented behaviour (54.30), which in turn accounts for more than change-oriented behaviour (45.22\%). They would however like to continue with approximately the same amount of task behaviours $(73.21 \%$ ) while increasing both relationsoriented behaviour (to 62.25\%), and change-oriented behaviour (to $62.28 \%$ ). This shows that there is still much relevance for the task behaviours in Indian SMEs. But from the research we have done, it is evident that the Indian SME leaders have realized the need to move to a change oriented leadership. 
With regard to identifying specific areas for leadership training, the survey suggests that the following areas have to be concentrated.

- Encourage people to view problems or opportunities in a different way

- Experiment with new approaches for achieving objectives

- Encourage and facilitate innovation and entrepreneurship in the organization

- Develop innovative new strategies linked to core competencies

- Help resolve conflicts in a constructive way

- Express confidence that a person or group can perform a difficult task

- Socialize with people to build relationships

- Keep people informed about actions affecting them

- Provide coaching and mentoring when appropriate

- Recruit competent new members for the team or organization

- Use symbols, ceremonies, rituals and stories to build team identity

- Set specific goals and standards for task performance

- Clarify what results are expected for a task

- Monitor operations and performance

- Direct and coordinate work activities

- Explain rules, policies, and standard operating procedures

There is also evidence from the survey, by considering averages responses of $75 \%$ and over, that the SME leaders are currently focusing on the three task-oriented behaviours; assigning work to groups or individuals, setting specific goals and standards for task performance and resolving immediate problems that would disrupt the work. They also concentrate on one relations-oriented behaviour, providing support and encouragement to someone with a difficult task. 


\section{References}

Atkins, M.H. and Lowe, J.F. (1996). "Sizing up the small firms: UK and Australian experience", International Small Business Journal, 15 (3), 44-55.

Barrier, M. (1994). "Re-engineering your company", Nation's Business, 82 (2), 16-28.

Barnard, C.I. (1948). "The Nature of Leadership," in C. I. Barnard Organisation and Management, Selected Papers. Boston: HBR Press.

Bryman, A. (1992). Charismatic Leadership in Organisations. London: Sage

Collinson, D. and Grint, K. (2005). Editorial: The leadership agenda, Leadership, 1: 5-9.

Dubrin, J. (2000). Leadership. London: Houghton Mifflin.

Gronn, P. and Ribbins, P. (1996). "Leaders in Context: Post-positivist Approaches to Understanding Educational Leadership," Educational Administration Quarterly 32(3): 452-73.

Kacker, S. N. (2005), "Overcoming Barriers to Innovation for Indian SMEs", International co-operation to seize Innovation opportunities for SMEs Conference, Barcelona, Spain.

Man, T.W., Lau, T. and Chan, K.F. (2001). "The competitiveness of small and medium enterprises: A conceptualization with focus on entrepreneurial competencies, "Journal of Business Venturing, 17 (2), 123-42.

McAdam, R., (2000). "The implementation of reengineering in SMEs: A grounded study," International Small Business Journal, 18, 4, 29-45.

Mitroff, I. (1978). 'Systematic Problem Solving' in M. W. McCall, Jr and M. M. Lombardo (eds). Leadership: Where Else Can We Go? Durham: Duke University Press.

Nanjundan S. (1994) Changing role of small scale indusiry: International influences, country experiences and lessons for India. Economic and Political Weekly. 29 (22) pp 46-63.

Stogdill, R. M. (1974). Handbook of Leadership. New York: Free Press.

Yukl, G. A. (2005). Leadership in Organisations (6 $6^{\text {th }}$ ed.). Upper Saddle River, NJ: Pearson, Prentice Hall.

Yukl, G. A., Gordon, A. and Taber, T. (2002). "A Hierarchical Taxonomy of Leadership Behaviour: Integrating a Half Century of Research," Journal of Leadership and Organisational Studies, 9 (1), 15-32. 